\title{
SEME STOCKS OF LEXIC0-SEMANTIC FIELDS - A CONTRASTIVE STUDY
}

The approach to the contrastive study of lexico-semantic fields and their stocks by the method of a matrix analysis is entirely new in lexical semantics. In our research paper we present the results of a comparative analysis carried out on the seme stocks of lexico-semantic fields of the nouns denoting happiness both in English and Slovak. It was preceded by dictionary analyses for the purpose to find and collect all the specified nouns. Their forms and meanings were consequently quantitatively and qualitatively analysed. The objectives of the present lexicosemantic comparison are: a character of the seme stock, individual and common meanings of English and Slovak nouns of happiness and their semantic reference to three domains of human personality.

Key words: componential analysis, matrix, lexico-semantic field, seme stock, comparative analysis

\section{Componential analysis}

Semantic structure of words is studied by the methods of componential and structural analyses which are interrelated. Componential analysis (CA) or lexical decomposition - as one of the main methodologies of structuralist semantics - is a logical development from the lexical field theory as it describes the sense relations among lexemes of a specific field in a formalized, precise, and detailed way. By application of this form of semantic analysis individual meanings of polysemantic words with different componential structure are decomposed into the smallest, further unanalysable semantic components or features - semes. Semes of various level of abstraction are subsequently hierarchically ordered in a highly structured system. They determine the semantic-syntactic environment of the word and influence the choice of other elements the word will be connected with.

\subsection{Historical background}

CA as a method for describing mutual oppositions between the lexical units of the field has been used since the second half of 1950s by American linguists (e.g. Floyd G. Lounsbury, Eugene Nida, Ward Goodenough, Brent Berlin, Paul Kay, and Wilhelm von Humboldt) as well as European linguists (e.g. Louis Hjemslev, Bernard Pottier, Eugenio Coseriu, Uriel Weinrich, Jerrold J. Katz, and Jerry A. Fodor) who found the common inspiration in structural phonology. American anthropologists used CA for kinship terms, personal pronouns, gradable antonyms, and colour terms. Louis Hjemslev applied it on certain sets of animals and Katz and Fodor on dictionary definitions. In their theory, Katz and Fodor used the terminology of semantic markers (present in the lexical meaning of the studied word as well as in the meanings of other words) and semantic distinguishers which make the studied word specific and unique [1].

\subsection{Matrix of lexico-semantic field (LSF)}

In the present componential approach we replaced binary features [2], i.e. a traditional and oversimplified organizing principle of semantic analysis, by a two-dimensional structure - a matrix. All lexical units (with all their meanings) obtained by an entire dictionary analysis of two selected explanatory dictionaries were placed in it. Thus we managed to find and study semantic interconnections between the related meanings of different lexical units as well as between different meanings of a specific lexical unit.

In general, a matrix is a rectangular array of objects with a finite or infinite number of lines and columns. An item in a matrix is called an element or segment [3]. If we understand a lexical meaning of the word as a reflective category and if the reflection of reality in the human mind is characterized by the form of a lexeme, depiction of relations among individual units of language becomes very effective and precise when a matrix adapted for this specific aim is used. There are two intersecting dimensions represented by horizontal and vertical axes. The vertical one indicates a lexical stock and the horizontal one indicates a seme stock of the collected language material (see Fig. 1 and Fig. 2).

The composition of a matrix requires an application of a weight theory, by which each element of the seme stock is given different weight. The weight of an investigated lexeme equals the sum of weights of its meanings. The more the meaning is to the left of the

\footnotetext{
* Eva Lelakova

Faculty of Humanities, University of Zilina, Slovakia, E-mail: eva.lelakova@fpv.uniza.sk
} 
horizontal axis, the lower its weight is. That means that if the number or importance of the meanings of a lexeme changes, or even if the word ceases to be important for the research, the matrix can be instantaneously readjusted and the work with the updated data is carried out.

\section{Language data}

\subsection{Lexical stock}

Happiness lexis of the present Slovak language is formed by 165 nouns. It is quantitatively smaller in comparison with the English one which contains 199 nouns. English and Slovak nouns of happiness are arranged according to the degree of polysemy [4] in descending order and put on vertical axes of the Matrices of LSFs (see Table 1, Fig. 1-2).

Lexical stock of English and Slovak nouns

Tab. 1 denoting happiness

\begin{tabular}{|l|c|c|c|c|}
\hline Degree of polysemy & \multicolumn{2}{|c|}{ English lexemes } & \multicolumn{2}{c|}{ Slovak lexemes } \\
\hline High & 27 & $13.56 \%$ & 1 & $0.61 \%$ \\
\hline Middle & 102 & $51.26 \%$ & 19 & $11.52 \%$ \\
\hline Low & 60 & $31.16 \%$ & 101 & $61.21 \%$ \\
\hline Monosemantic nouns & 10 & $5.02 \%$ & 44 & $26.66 \%$ \\
\hline Total & 199 & $100 \%$ & 165 & $100 \%$ \\
\hline
\end{tabular}

\subsection{Seme stock}

The seme stocks of English and Slovak language material are obtained by an application of CA. They contain semes which were singled out from the meanings of English and Slovak nouns of happiness. Our approach to semantic analysis presupposes the fact that the meaning of every lexeme can be analysed in terms of its semantic components which can be either specific for an individual lexeme or common for several different lexemes of the field. Thus, different meanings of the nouns of happiness are expressed and precisely distinguished by the combination of certain semantic features or semes. This helps us to define more economically and precisely the semantic relations between the nouns and specifies what components of meaning either connect or differentiate the lexical units under study.

\subsubsection{Seme stock of English nouns denoting happiness}

The seme stock of the nouns denoting happiness in modern English language is made up of 159 semes. The method of CA is applied on all lexical meanings of the collected nouns and is justified due to the fact that the meanings of the nouns denoting happiness consist of semes by which all the English vocabulary can be described.
The semes are divided into 6 groups and put on the horizontal axis of the Matrix of LSF of the nouns denoting happiness in English. Their classification is done on the basis of the frequency of their occurrence in semantic structures of the nouns, i.e. according to their degree of functionality. Thus we distinguish polyfunctional semes, semes with a limited functionality and monofunctional semes (see Table 2). M. Fabian mentions "chain correlations" and claims that the lexical meanings of the English nouns denoting happiness are interrelated and one can be explained through the other, the second through the third, etc. Chain correlations can thus explain the repetition of the same signs in the structural organization of lexical units [5]. On the basis of our research we also agree with her assumption that the more often the seme is met in the lexical meanings of a big quantity of words, the more general and more deprived of emotional colouring it is [6].

We can illustrate it on the following examples:

1. state, condition of; one who...; expression of; means of, instrument of are polyfunctional, very abstract, and general semes of the field,

2. payment; bravery; shining; fit, attack are less functional semes with a stronger semantic colouring.

Seme stock of English nouns denoting happiness

Tab. 2

\begin{tabular}{|c|c|c|c|l|}
\hline Groups & \multicolumn{2}{|c|}{ Semes } & Number of lexemes & Degree of functionality \\
\hline I. & 15 & $9.4 \%$ & $96-19$ & Polyfunctional \\
\hline II. & 12 & $7.5 \%$ & $17-8$ & Polyfunctional \\
\hline III. & 21 & $13.2 \%$ & $7-4$ & Polyfunctional \\
\hline IV. & 16 & $10.7 \%$ & 3 & Limited functionality \\
\hline V. & 26 & $15.7 \%$ & 2 & Limited functionality \\
\hline VI. & 69 & $43.4 \%$ & 1 & Monofunctional \\
\hline Total & 159 & $100 \%$ & & \\
\hline
\end{tabular}

\subsubsection{Seme stock of Slovak nouns denoting happiness}

The seme stock of the nouns denoting happiness in the contemporary Slovak language includes 108 semes and is put on the horizontal axis of the Matrix of LSF of Slovak nouns denoting happiness. The semes are classified and divided into 4 groups on the same principle as the set of semes characterizing the meanings of the English nouns denoting happiness, i.e. according to their degree of functionality (see Table 3 ). Thus, we obtain 30 polyfunctional semes $\left(1^{\text {st }}\right.$ and $2^{\text {nd }}$ group $)$ which characterize the meanings of 21-4 nouns, 25 semes with a limited functionality ( $3^{\text {rd }}$ group) presenting the meanings of 3-2 nouns and 53 monofunctional semes ( $4^{\text {th }}$ group).

Declination of the emotional colouring indirectly depending on the semes' functionality can be seen from the following examples:

1. semes stav (occurs in the meanings of 21 polysemantic nouns of happiness), vlastnost (semantically interconnects 20 nouns) 
and prejav, preukazovanie (common for 18 nouns) are the most functional of all the semes under study and obviously they are very general,

2. semes laska ku, apatia are monofunctional and their emotional colouring is incomparably higher.

On the other hand, semes of a higher functionality have a higher degree of abstraction which is directly proportional to the rate of the integrity of the component of meaning in the language system. Semes stav; vlastnost; prejav, preukazovanie; frazeologizmy; prijemny, pozitivny pocit, etc. versus laska $k u$, apatia; titul; jedlo; hnutie; vzliet nutie, baldachyn, etc. confirm this statement.

Seme stock of Slovak nouns denoting happiness

Tab. 3

\begin{tabular}{|c|r|c|c|l|}
\hline Groups & \multicolumn{2}{|c|}{ Semes } & Number of lexemes & Degree of functionality \\
\hline I. & 10 & $9.26 \%$ & $21-10$ & Polyfunctional \\
\hline II. & 20 & $18.52 \%$ & $8-4$ & Polyfunctional \\
\hline III. & 25 & $23.15 \%$ & $3-2$ & Limited functionality \\
\hline IV. & 53 & $49.07 \%$ & 1 & Monofunctional \\
\hline Total & 108 & $100 \%$ & & \\
\hline
\end{tabular}

\section{Objectives of comparison}

In the present comparative analysis we concentrate on:

- the character of the seme stocks of LSFs of the nouns denoting happiness in English and Slovak,

- common and individual meanings of English and Slovak nouns denoting happiness and relations between them,

- the semantic reference of English and Slovak nouns denoting happiness to three domains of human personality.

\subsection{Character of the seme stocks}

As regards the contents of the seme stocks of English and Slovak nouns of happiness, the percentage share of English and Slovak polyfunctional, monofunctional semes, and semes with a limited functionality is nearly the same (see Table 4). The contrastive study of the collected English as well as Slovak semantic material results in the conclusion that the richer the seme stock of a concrete noun is, the more possibilities it has for the semantic relations with other nouns of the field. This is the reason why English nouns rest, love, fortune, relief, repose, etc. and Slovak nouns srdce, laska, pokoj, milost, etc. having the highest number of meanings within their LSFs, can serve as the main centres of semantic relationships in later stages of the research.

Monofunctional semes form the most numerous group of the seme stocks of English as well as Slovak LSFs of the nouns denoting happiness. The most polyfunctional semes have a general character in both languages. The range of English nouns, from the meanings of which these semes have been obtained is wider than the range of Slovak nouns - there is a lower amount of Slovak nouns with a high and middle degree of polysemy.

Seme stocks of English and Slovak nouns

Tab. 4 denoting happiness

\begin{tabular}{|l|c|c|c|c|}
\hline Degree of functionality & \multicolumn{2}{|c|}{ English semes } & \multicolumn{2}{c|}{ Slovak lexemes } \\
\hline Polyfunctional & 48 & $30.2 \%$ & 30 & $27.8 \%$ \\
\hline Limited functionality & 42 & $26.4 \%$ & 25 & $23.1 \%$ \\
\hline Monofunctional & 69 & $43.4 \%$ & 53 & $49.1 \%$ \\
\hline Total: & 159 & $100 \%$ & 108 & $100 \%$ \\
\hline
\end{tabular}

It is evident from the Matrices of LSFs of the nouns denoting happiness in Slovak and English that different meanings of polysemantic nouns have different componential structure and there exists a relation between lexemes and semes which can be notified as 1: $x$ for $x>1$ ( $x$ represents the number of semes). The only exception in the research is the case of monosemantic lexemes which are in one-to-one correspondence with the appropriate semes $(x=1)$.

\subsection{Common and individual meanings of English and Slovak nouns of happiness}

The results of a comparative analysis (carried out on both English and Slovak semes not having their correspondences in the Slovak and English seme stocks) show that semes in the English language refer to attributes of people as well as things that surround them more often than their Slovak counterparts. English semes differ from Slovak ones in indicating not only the interests and desires of people but also their ways of thinking, perception, awareness, and understanding the surrounding environment. General character of eighteen of them and indication of emotional expressiveness and compensation for an effort or of punishment by three of them make the mentioned English semes unique in this comparison, too.

On the other hand, Slovak semes refer more frequently to things that make the human life pleasant and comfortable and to psychological processes proceeding in human minds. As to physical processes and their indication by Slovak and English semes, the same number of Slovak and English semes has been collected. Expression of human abilities and activities bringing fun to everyday life and making it easier as well as expression of specific fields of study, research, and thought by English and Slovak semes is quantitatively very similar. Only one Slovak seme indicates the result of a human activity in comparison with its seven English counterparts. A part of atmosphere characterized by one Slovak seme does not have its counterpart in the English seme stock. 
Comparative analysis of English and Slovak semes

\begin{tabular}{|c|c|c|}
\hline Semantics of semes & $\begin{array}{l}\text { English } \\
\text { semes }\end{array}$ & $\begin{array}{l}\text { Slovak } \\
\text { semes }\end{array}$ \\
\hline psychological processes & 3 & 8 \\
\hline psychological states & 5 & 3 \\
\hline physical processes & 4 & 4 \\
\hline physical states & 4 & 6 \\
\hline human abilities & 2 & 3 \\
\hline results of human activities & 7 & 1 \\
\hline activities bringing fun to everyday life & 4 & 3 \\
\hline activities making the life easier & 6 & 5 \\
\hline activities making the life meaningful & 5 & 2 \\
\hline things making the life pleasant and comfortable & - & 7 \\
\hline a part of atmosphere & - & 1 \\
\hline $\begin{array}{l}\text { things/conditions/activities bringing } \\
\text { complications to life }\end{array}$ & 4 & 2 \\
\hline $\begin{array}{l}\text { specific fields of study, research, thought, } \\
\text { terminology }\end{array}$ & 3 & 4 \\
\hline generality of meaning & 18 & - \\
\hline attributes of things & 9 & - \\
\hline interests and desires of people & 2 & - \\
\hline way of thinking and perception & 6 & - \\
\hline human qualities & 10 & - \\
\hline emotional expressiveness & 1 & - \\
\hline compensation for sth & 2 & - \\
\hline Total number & 95 & 49 \\
\hline
\end{tabular}

\section{Semantic reference to three domains of human personality}

The semantic reference of the nouns denoting happiness to three major domains of human personality shows that the ten-

Tab. 5 dency of English people to be pleasant, emphatic, and helpful in social situations is comparable to that of Slovak people. On the other hand, English people are far more extrovert and assertive than Slovak people. Their emotional stability is also considerably higher in comparison with the emotional stability of Slovak people who have less self-confidence, assertiveness, and extroversion. It is connected with their troubled history, centuries of Hungarian oppression, and decades of communist regime. They are sensitive to criticism, to being called Eastern-Europeans or Czechoslovakians. They desire for recognition as a mature European state with its own national identity [7].

\section{Conclusion}

Having studied the common meanings of English and Slovak nouns of happiness, we come to the conclusion that both English and Slovak people realize that a necessary condition of obtaining happiness is to concentrate on positive things, ideas, and values in their lives, to use all energetic potential and find emotional stability which will enable them to make important changes in their lives. A higher power or universal intelligence are very often the sources of their inner peace, and support them in various life situations.

People of both nations seek satisfaction and happiness also in some form of external convivial entertainment or festive dissipation. They are open to manifestation of their feelings, and thoughts. Expressions of their attitudes to active and passive entertainment as well as relations to people, who deserve attention, are very similar, too.

Both English and Slovak languages are characterized by the presence of extensive seme stocks, and semantic reactivity of polysemantic nouns denoting happiness not only with other nouns of the fields of happiness but also with the nouns of other fields of English and Slovak lexis. Typological comparison of LSFs of the nouns denoting happiness has shown their common, partially common, as well as unique qualitative and quantitative features.

\begin{tabular}{|l|l|l|}
\hline & English nouns & Slovak nouns \\
\hline Extraversion & $\begin{array}{l}\text { jocundity, zest, brio, cheerfulness, fervency, élan, enthusiasm, } \\
\text { ardour, zestfulness, vim, verve, vitality, exuberance, jubilation, } \\
\text { jocosity, elation, gusto, heartiness, pep, cordiality, jocoseness, } \\
\text { conviviality, lightsomeness, joviality, hilarity, sprightliness, } \\
\text { fervour, chirpiness, zestfulness, joyousness, friskiness, } \\
\text { jollification, alacrity, playfulness, frolicsomeness (35) }\end{array}$ & $\begin{array}{l}\text { zapal, elan, zapalenie, zapalenost, odusevnenie, verva, } \\
\text { odusevnenost, nadsenie, nadsenost, entuziazmus, } \\
\text { nadchnutie, nadchnutost, horlivost, veselost, vitalnost (15) }\end{array}$ \\
\hline Agreeableness & $\begin{array}{l}\text { warm-heartedness, beneficence, benefaction, altruism, } \\
\text { kindliness, goodwill, philanthropy, optimism, heartiness, cor- } \\
\text { diality, amity, affectionatess, amiableness, amiability, } \\
\text { pleasantness, pleasurableness, tenderness, fondness (18) }\end{array}$ & $\begin{array}{l}\text { dobrota, dobromyselnost, dobrodusnost, dobroprajnost, } \\
\text { dobrosrdecnost, ziclivost, privetivost, dobrodenie, } \\
\text { dobrodinstvo, dobrackost, dobractvo, blahovolnost, blaho- } \\
\text { prajnost, dobrocinnost, filantropia, ludomilnost, altruizmus, } \\
\text { optimizmus, priatelskost, neznost (20) }\end{array}$ \\
\hline Emotional stability & $\begin{array}{l}\text { soundness, calmness, contentedness, placidness, placidity, } \\
\text { tranquillity, peacefulness, stillness, quiet, fulfilment, equanim- } \\
\text { ity, serenity, comfortableness, lightheartedness, reposefulness } \\
(\mathbf{1 5})\end{array}$ & $\begin{array}{l}\text { pokoj, vyrovnanost, mier, pohoda, rovnovaha, vyrovnanost, } \\
\text { pokojnost, uvolnenost (8) }\end{array}$ \\
\hline
\end{tabular}




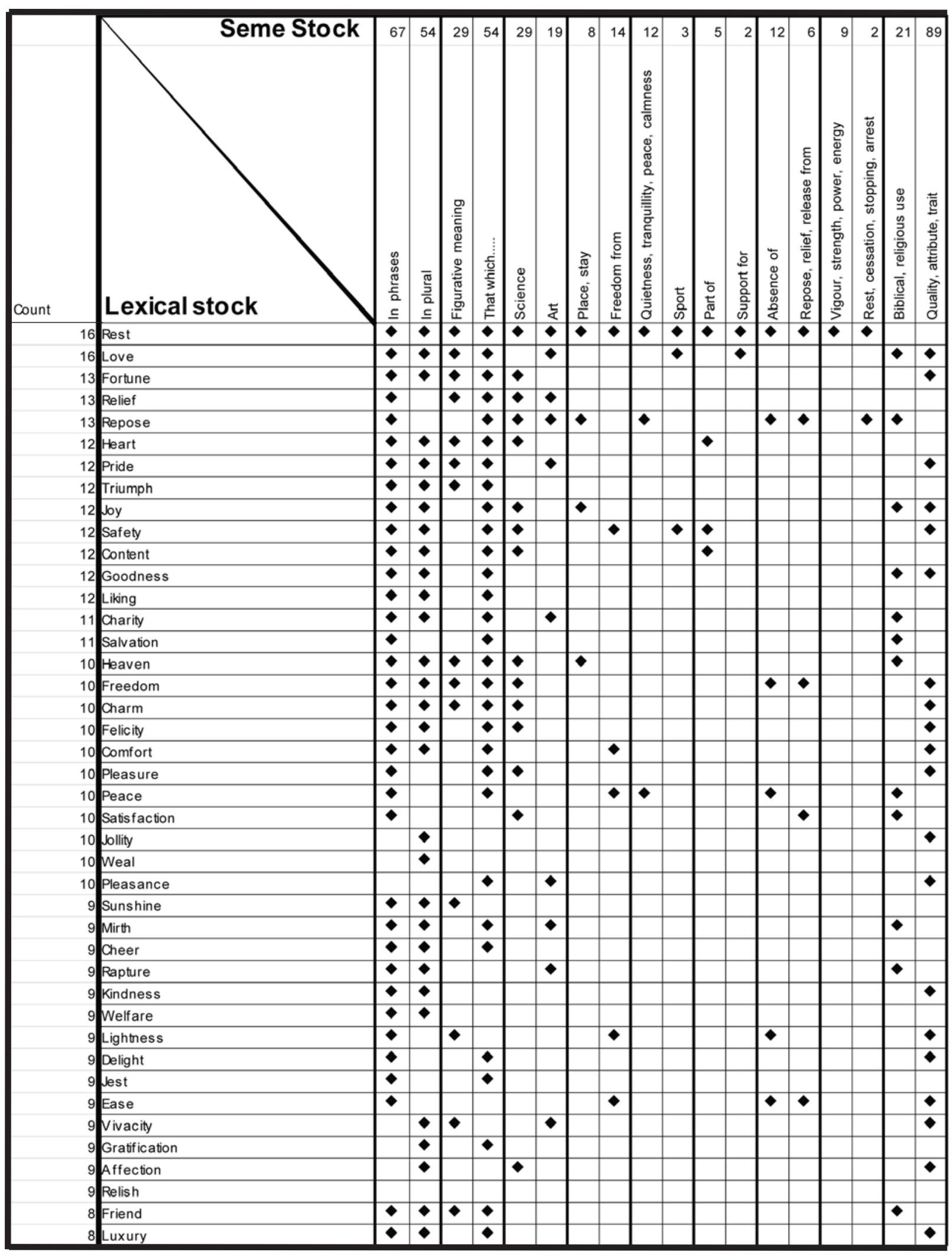

Fig. 1 Matrix of LSF of English nouns denoting happiness - upper left part 


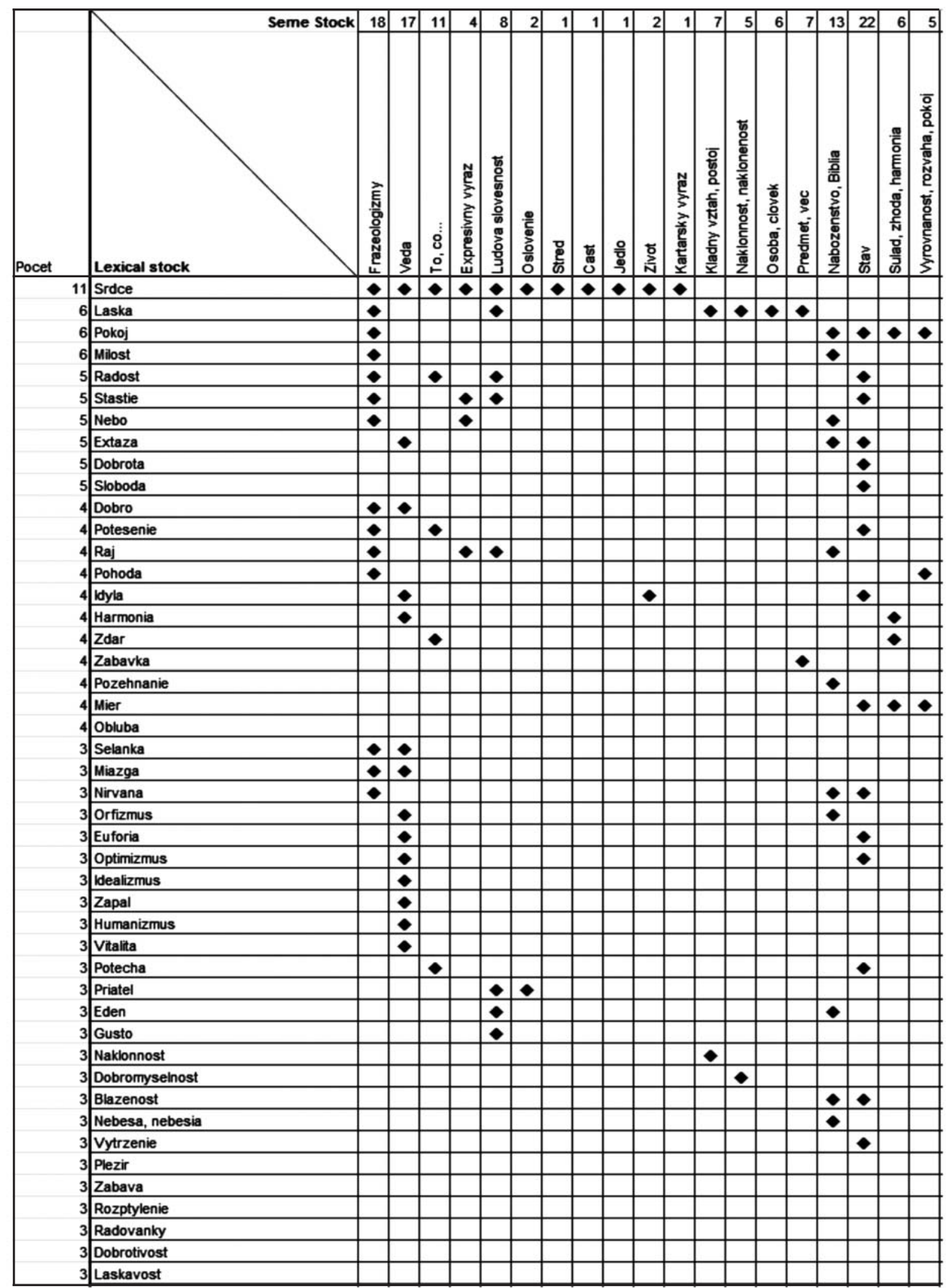

Fig. 2 Matrix of LSF of Slovak nouns denoting happiness - upper left part 
Especially remarkable are quantitative distinctions - i.e. different amount of semes characterizing the lexical meanings of the nouns under comparison.

On the basis of the research we came to a conclusion that English and Slovak nouns together with their meanings do not fill the same semantic space in their LSFs and do not have the same semantic character. Their LSFs have their own unique and origi- nal external and internal structures, and relations between their specific elements. They present national, social, cultural, and individual peculiarities of happiness expression, fix collective stereotypes, physical and mental states and processes of people. Furthermore, elements of both LSFs also speak for the existence of general and deep semantic relations, conditioned by logically-psychological mechanism of human thinking.

\section{References}

[1] KATZ, J. J., FODOR, J.A.: The Structure of a Semantic Theory, Language, Vol. 39, 1963, No. 2, pp. 170-210.

[2] KRALOVA, Z.: Mathematical and Statistical Analysis of the Selected Factors of English Phonetic Competence (in Slovak), Acta humanica: Philology, 2009, No. 1, pp. 60-79.

[3] KARRIS, S. Numerical Analysis. Using MATLAB and Spreadsheets, $2^{\text {nd }}$ Edition, Fremont: Orchard Publications, 2004.

[4] BABIJ, O.I.: Comparison of Ukrainian and English Polysemantic Words Denoting Human Emotional Sphere (in Ukrainian), Current Language and Literature Studies, Vol. 5, 2007, pp. 28-33.

[5] FABIAN, M.: Etiquette Lexis in Ukrainian, English and Hungarian Languages (in Ukrainian), Uzhorod: IBA, 1998.

[6] FABIAN, M.: Etiquette Lexis in Ukrainian, English and Hungarian Languages (in Ukrainian), Uzhorod: IBA, 1998.

[7] LEWIS, R. D.: When Cultures Collide. Leading Across Cultures, London : Nicholas Brealey International, 2006. 